\title{
Marketing to America's youth: evidence from corporate documents
}

\author{
K M Cummings, C P Morley, J K Horan, C Steger, N-R Leavell
}

Tobacco Control 2002;11(Suppl I):i5-i17

See end of article for authors' affiliations

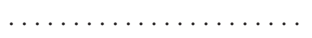

Correspondence to: K Michael Cummings, PhD, $\mathrm{MPH}$, Department of Cancer Prevention, Epidemiology \&

Biostatistics, Roswell Park Cancer Institute, Elm and Carlton Streets, Buffalo, New York 14263, USA; Michael.Cummings@ Roswellpark.org

\begin{abstract}
Objective: To evaluate the claim that the tobacco industry does not market its products to youth. Design: The data for this study come from tobacco industry documents collected from the tobacco industry's document websites, presently linked at http://www.tobaccoarchives.com. The websites were searched using "request for production" (RFP) codes, specified keyword searches, and serendipitous terms identified in document citations found with RFP and keyword searches.

Results: Industry documents show that the cigarette manufacturers carefully monitored the smoking habits of teenagers over the past several decades. Candid quotes from industry executives refer to youth as a source of sales and as fundamental to the survival of the tobacco industry. The documents reveal that the features of cigarette brands (that is, use of filters, low tar, bland taste, etc), packaging (that is, size, colour and design), and advertising (that is, media placements and themes and imagery) were developed specifically to appeal to new smokers (that is, teenagers). Evidence also indicates that relevant youth oriented marketing documents may have been destroyed and that the language used in some of the more recent documents may have been sanitised to cover up efforts to market to youth. Conclusions: The tobacco industry's internal documents reveal an undeniable interest in marketing cigarettes to underage smokers. The industry's marketing approaches run counter to and predicate methods for tobacco prevention: (1) keep the price of the product high; (2) keep product placements and advertising away from schools and other areas with a high volume of youth traffic; (3) make cigarette advertising (that is, themes and visual images) unappealing to youth; (4) make product packaging unappealing to youth; and (5) design the product so it is not easy to inhale.
\end{abstract}

C igarette manufacturers have stated that they do not want minors to smoke. ${ }^{12}$ In the 1960s, cigarette manufacturers responded to charges that they were marketing their tobacco products to youth by making concessions in how tobacco products were marketed through adoption of a voluntary advertising code. ${ }^{3}$ More recently, they have agreed to limitations on billboard and print advertising and implemented retailer education programmes like "We Card" and "Action Against Access".4-6 Over the past two decades, cigarette manufacturers, either through their public relations and lobbying surrogate, the Tobacco Institute, or on their own, have expended resources to sponsor youth and parent directed prevention programmes to promote the message that the decision to smoke should be reserved for adults. ${ }^{178}$

However, beneath the layers of industry public relations one cannot escape the essential fact that cigarette manufacturers are in business to make a profit and their profits depend on their ability to recruit new smokers. Given the evidence that most adult smokers begin smoking before the age of 18 years and few smokers ever take up smoking after age 25 , it would be counterproductive for an industry that thrives on market share to overlook the specific customer demographic in which initial brand loyalties are formed. ${ }^{9}$ Brand switching is not that common among smokers, usually less than $10 \%$ annually. ${ }^{10}$ Therefore, there is a strong incentive for a company to compete for market share among beginning smokers, since the long term prosperity of a given cigarette brand and company will depend on the percentage of new smokers that can be captured annually. ${ }^{11}$ The public health literature clearly demonstrates that youth are exposed to a wide variety of industry marketing efforts, and that there is a consequent adverse effect upon adolescent smoking initiation rates. ${ }^{12-16}$ Despite this evidence, cigarette manufacturers have tenaciously held to the claim that their marketing activities are aimed only at established adult smokers, with the goal of maintaining market share and expanding market share through brand-switching. ${ }^{2}$

The tobacco litigation of the 1990s has provided the public health community with an opportunity to evaluate marketing claims made by the tobacco industry from the perspective of their own internal memoranda, marketing plans, and research reports. This paper presents the results of a study utilising internal tobacco documents to evaluate critically the claim of tobacco manufacturers that they have never marketed tobacco products to youth $(<18$ years old). We have focused on two research questions:

- Is there evidence to show that cigarette companies were interested in the smoking behaviour of teenagers?

- Do the tobacco documents identify features of tobacco product marketing that are geared to new smokers?

\section{METHODS}

As a result of the Master Settlement Agreement (MSA) between the cigarette manufacturers and 46 US states, millions of pages of internal memoranda, reports, and other documents of tobacco companies initially acquired through litigation were made available to the public. These files are accessed through a document depository located in Minneapolis, Minnesota and through an internet website at http://www.tobaccoresolution.com, that links to individual company websites. For this study, relevant industry documents were accessed through document websites for Brown \& Williamson/American Tobacco, Lorillard, Philip Morris, and RJ Reynolds.

The websites presented a variety of challenges to efficient researching of documents. The most fundamental challenge facing researchers is the difficulty associated with doing subject related searches (for example, cancer, nicotine, etc) like one would typically do in a library using a card catalogue. Unfortunately, the industry generated document resources

Abbreviations: FUBYAS, first usual brand young adult smokers; MSA, Master Settlement Agreement; RFP, request for production; YAMS, younger adult male smokers; YAS, young adult smokers 
(that is, the websites and depositories, and the corresponding $4 \mathrm{~B}$ index) are not organised by subject category. Each document that is available through these sources has a citation associated with it, containing information such as the title, date, author, and "request for production" (RFP) code of the document. The citation data objectively catalogues information about each document, but does not offer more than a hint as to content. Additionally, the quality of the hosted images was highly variable, ranging from clear to illegible. Finally, as previously mentioned, the structure of each of the industry websites varied over the course of the acquisition phase. Each website has continuously changed in terms of interface format, search features, and document collection, to this day. Malone and Balbach have recently described some of the challenges in searching the tobacco document websites in greater detail. ${ }^{17}$

In order to maximise our search effort for documents relevant to the topic of marketing tobacco products to youth, we used the following four strategies.

\section{Strategy 1}

We searched company websites using RFP codes. In response to a request from plaintiff lawyers in the Minnesota Medicaid trial, the industry produced internal documents related to specific litigation goals, and broad subject codes were assigned to distinguish between sets of materials. These codes offer very rudimentary subject access to the documents. For example, code "I93" for Brown \& Williamson requested the following:

"All documents relating to or referring to the advertising, marketing, or promotion of cigarettes to persons age 18 or under (or children, adolescents or young adults)."

Searching with a relevant code retrieves all documents deemed by each company as relevant to a particular code. The definition of these codes are found on each company website. This poses obvious limitations to investigators performing complete searches. In addition to the fact that the tobacco companies themselves (or their attorneys, to be more specific) were responsible for the application of this code, the volume of material contained within each RFP code is large. Not all of the documents listed under a particular RFP code were found to be relevant to the topic of this study (that is, marketing tobacco products to youth). Documents that were irrelevant to the topic of this study were not downloaded or saved for inclusion in the project's database. In all cases, search results (that is, the total body of document citations retrieved by each search term or string employed) needed to be evaluated carefully, since irrelevant material is almost always included in the results. This is due in large part to the lack of true subject access, as previously noted.

\section{Strategy 2}

We performed broad and focused keyword searching. Broad keyword searching involves searching on single keywords such as "youth" or "marketing" to capture the maximum amount of hits with the keyword located anywhere in the document citations, usually the title field. This method of searching typically produces a very large volume of documents (in some cases thousands). We reduced the large volume of documents retrieved through the use of focused keyword searching. This was achieved by combining keywords with Boolean operators (AND, OR, NOT) and by searching in specified fields to retrieve documents with keywords only as they appear in that field. It should be noted that the search engines at individual websites are frequently modified and updated, and specific characters or Boolean terms in use in 1999 may function differently now.

Focused keyword searches facilitated retrieval of documents that reflected the needs of the study by eliminating documents that were clearly unwanted (that is, blank pages, copies of research reprints, newspaper clippings etc). It is

\begin{tabular}{|c|c|}
\hline AAA & point of purchase \\
\hline access & point of sale \\
\hline $\begin{array}{l}\text { Action Against Access } \\
\text { advertis* }\end{array}$ & $\begin{array}{l}\text { point-of-purchase } \\
\text { point-of-sale }\end{array}$ \\
\hline $\begin{array}{l}\text { behavior } \\
\text { billboard }\end{array}$ & $\begin{array}{l}\text { pos } \\
\text { prefer* }\end{array}$ \\
\hline Camel & prevention \\
\hline campaign & pric* \\
\hline candy & print \\
\hline cessation & product \\
\hline chew* ${ }^{*}$ & Project \\
\hline child* & promot* ${ }^{*}$ \\
\hline cigar* & radio \\
\hline college student & research \\
\hline confection & Responsible Living Program \\
\hline consum* & Responsible Retailer Program \\
\hline coupon* & Right Decisions Right Now \\
\hline direct mail* & Salem \\
\hline event sponsorship & sampling \\
\hline first usual brand & select* ${ }^{*}$ \\
\hline FUBYAS & self-help display \\
\hline Golden Lights & smok* \\
\hline Harley Davidson & smokeless \\
\hline Helping Youth Decide & starter \\
\hline Helping Youth Say No & stud* \\
\hline incidence & $\begin{array}{l}\text { Support the Law - It Works } \\
\text { survey* }\end{array}$ \\
\hline $\begin{array}{l}\text { interview } \\
\text { It's the Law }\end{array}$ & $\begin{array}{l}\text { survey } \\
\text { turk }\end{array}$ \\
\hline Kool & television \\
\hline loyal* & teen ${ }^{*}$ \\
\hline mall & target* \\
\hline market* & t.v. \\
\hline Marlboro & switch* \\
\hline media budget & pop \\
\hline media expen* & vending \\
\hline $\operatorname{minor}^{*}$ & Winston \\
\hline movie $^{*}$ & withdrawal \\
\hline new smoker & YA \\
\hline Newport & YAF \\
\hline $\mathrm{OOH}$ & YAM \\
\hline out of home & YAS \\
\hline out-of-home & young adult (YA) \\
\hline p.o.p. & younger audience \\
\hline p.o.s. & youth \\
\hline packaging & young smoker \\
\hline & young \\
\hline
\end{tabular}

important to note that while all tobacco companies are mandated to have particular searchable fields on their websites (for example, Title, Author, Bates Number/Document ID, etc), successfully accessing these fields varies from one company to another. $^{18}{ }^{19}$

\section{Strategy 3}

We performed serendipitous searches. Without being able to perform subject searches based on a controlled vocabulary (that is, a standardised set of terms used to organise a collection of documents, books, etc, by concept), we did not know, a priori, all terms used within the documents to refer to people under the age of 18. This necessitated a serendipitous keyword search strategy. Through this method, we identified numerous youth related terms to assist in acquiring related documents. These terms are shown in table 1 along with a partial list of keywords used in both broad and narrow searching for youth related documents.

\section{Strategy 4}

Smaller collections of documents were also acquired from state and civil suits against the industry. To reduce duplication, each document obtained from these sources was checked against documents already acquired, using Bates range as the unique identifier. In the case of missing or questionable Bates range, each document was checked using author, title and 
date. It is also important to note that pursuant to the MSA, the industry is required to post to its website all documents produced in subsequent litigation. While our study was able to acquire documents directly from plaintiff law firms, in theory these documents also appear on the industry websites.

Our document search resulted in the acquisition of approximately 5500 industry documents, the majority of which were pertinent to the topic of marketing tobacco products to youth. Searching of the documents was completed in July 2001. Documents retrieved were dated from the 1930s to the mid 1990s. Most of the documents (86\%) in our collection were acquired from the tobacco company websites.

A possible fifth strategy could have been the acquisition of documents from the Minnesota Depository. However, we found that searching at the Minnesota Depository was no better in acquiring new documents than obtaining them through the tobacco company websites. We have informally compared lists of relevant documents on youth marketing (verified by comparison of Bates numbers) identified through our searching of the industry websites with document lists generated by ourselves and others who have visited the Minnesota Depository. In general, we found good agreement between the documents acquired via the industry websites and documents located through the Depository. A recent study comparing acquisition of documents via the internet as opposed to the Depository has confirmed our observation that document acquisition is similar between the internet and the Depository. ${ }^{20}$

\section{Cataloguing and abstracting}

After acquisition, each document was catalogued in a Microsoft Access database. Each document received a unique identifier within the collection. However, for external reference purposes, Bates numbers were also included in the database. The Bates number is a unique identifying number that was assigned by each producing party to each page of the tobacco industry documents when the documents were produced in litigation. These numbers can be used to search for documents in the 4B Index, the Minnesota Select Set, and on the Tobacco Industry Documents website. Bates numbers are either numeric or alpha/numeric. The label "Bates Number" comes from the name of the machine-Bates-that is used to stamp numbers onto pages of documents. ${ }^{21}$ Following the initial cataloguing of documents, each document was then reviewed by a professional librarian or other project member trained in the study's indexing methods. Each document was assigned a maximum of 12 subject headings, and terms were weighed between two major and 10 minor subject headings based on content. Target market (young adult smoker, Latino, African American, FUBYAS ["first usual brand young adult smokers"], etc) and marketing type (billboard, coupon, point of sale, etc) were assessed and recorded. Additionally, an abstract was written for each document.

Abstracting offers a researcher a quick but comprehensive look into the content of a document, greatly facilitating research when working with a large document collection. To maintain the integrity and consistency of our work, two separate reviewers evaluated each document for subject content. All of the documents acquired for this study along with abstracts are searchable and available online at http:// roswell.tobaccodocuments.org under the heading "Roswell Park Youth and Marketing Collection".

\section{RESULTS}

Evidence of interest in the smoking behaviour of teenagers Within the "Roswell Park Youth and Marketing Collection" we found 268 out of the approximately 5500 documents in the collection tagged with the minor subject heading "Youth ( $<18$ years old) market research", ranging in date from the 1950s through the mid 1990s. These documents reveal that tobacco companies routinely researched the smoking habits of teenagers and competed vigorously with each other to design products and marketing plans to capture a share of the youth smoking market. For example, a 1974 report to the RJ Reynolds' board of directors explicitly states the company's interest in capturing market share among younger smokers, defined as those between the ages of 14-24 years: "Thus, our strategy becomes clear for our established brands-direct advertising appeals to the younger smokers."22 This report goes on to outline plans for the mass distribution of $\mathrm{T}$ shirts and other promotional items at beaches and expansion of Reynolds' sponsorship of NASCAR auto racing because $63 \%$ of spectators are under the age of 35.

A 1978 memorandum from a Lorillard executive commented on the success of their Newport brand noting that "the base of our business is the high school student."'23 An undated (estimated 1984) Brown \& Williamson Tobacco Company marketing research report notes that their Kool cigarette brand had a young age profile including teenagers: "The largest proportion of Kool smokers are between 16 and 25 years of age."24

Philip Morris company documents demonstrate a longstanding interest in the smoking behaviour of teenagers. As early as the 1960s Philip Morris had commissioned studies examining the smoking habits of teenagers as young as 12 and 13 years. One 1963 study examined the brands smoked by teenagers aged 13-18 years, how much they smoked, what prompted them to begin smoking, and how often they bought cigarettes from vending machines. ${ }^{25}$ A separate 1973 memorandum addressed to the vice president of Philip Morris, James Morgan, discussed results of a survey commissioned by Philip Morris aimed at youths between 12-17 years of age who smoked more than a pack a day. ${ }^{26}$ When questioned about these studies during the Minnesota Medicaid trial, $\mathrm{Mr}$ Morgan explained that these studies were "embarrassing anomalies" for the company. ${ }^{27}$ However, other company documents clearly demonstrate that during the 1970s and 1980s, Philip Morris was well aware of the fact that its Marlboro brand was the preferred cigarette brand smoked by teenagers. A 1981 Philip Morris research report entitled "Young smokers: prevalence, trends, implications and related demographic trends", expressed the importance of understanding factors motivating teenagers to start smoking as follows: "It is important to know as much as possible about teenage smoking patterns and attitudes. Today's teenager is tomorrow's potential customer, and the overwhelming majority of smokers first begin to smoke while still in their teens."'28

Table 2 provides a partial listing of statements on youth marketing from documents we acquired from the websites of Brown \& Williamson, Lorillard, Philip Morris, and RJ Reynolds. ${ }^{22} 28-49$

\section{Using code words to describe underage smokers}

Statements about selling cigarettes to youth were made explicitly and often in documents dating before the mid 1970s. However, our analysis suggests that direct references to the marketing and sale of tobacco products to minors began to disappear in documents starting in the late 1970s. At this time, the term "young adult" (YA), generally meaning those 18-20 years of age, began to replace the term youth. Several documents indicate that the shift away from use of the term "youth" in internal correspondence was a matter of policy. For example, a 1975 memorandum written by a Brown \& Williamson executive states, "from time to time when describing market categories and target audiences we use references such as 'young smokers', 'young market', 'youth mar-

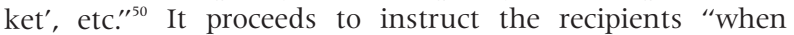
describing the low-age end of the cigarette business please use the term 'young adult smoker' or 'young adult smoking mar-

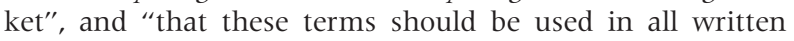
materials in the future".$^{50}$

Similar instructions were relayed to employees of RJ Reynolds Tobacco Company in a 1981 memorandum that 
Table 2 Industry documents containing statements on marketing tobacco products to youth

\begin{tabular}{|c|c|c|c|c|}
\hline Ref No. & Year & Company & Title & Comment \\
\hline 29 & 1974 & $B \& W$ & $\begin{array}{l}\text { Young adult smoker life styles and } \\
\text { attitudes }\end{array}$ & $\begin{array}{l}\text { "The purpose of this research was to gain insight into the perceptions, antitudes } \\
\text { and behavior of younger, recently-starting smokers ..." "Many talked about first } \\
\text { trying a cigarette before the age of ten." }\end{array}$ \\
\hline 30 & 1975 & $B \& W$ & $\begin{array}{l}\text { Re: Kool analysis of brand switching } \\
\text { study-wave \#18 }\end{array}$ & $\begin{array}{l}\text { "Kools effort against the 16-25 age group ["young smokers"] continues to be } \\
\text { working" }\end{array}$ \\
\hline 31 & 1976 & B\&W & Subject: Pontiac Kool jazz festival & $\begin{array}{l}\text { "Audience composition covered the age spectrum with a slight skew toward the } \\
16-25 \text { age group." }\end{array}$ \\
\hline 32 & 1977 & B\&W & Re: Meeting minutes of $B \& W$ problem lab & $\begin{array}{l}\text { "Contact leading firms in terms of children research ....contact Sesame } \\
\text { Street . . . contact Gerber, Schwinn, Mattel ..." "Determine why these young } \\
\text { people were not becoming smokers." }\end{array}$ \\
\hline 33 & 1978 & $B \& W$ & $\begin{array}{l}\text { Session \#3 Implications for cigarette } \\
\text { industry }\end{array}$ & "Imagery will continue to be important in brand selection for teenagers." \\
\hline 34 & 1983 & $B \& W$ & Cinema advertising-possibilities & $\begin{array}{l}\text { "(The Kool spot) is upbeat, hip and remains consistent with the image the brand } \\
\text { attempts to promote. Owing to the plot and the catchy music (lyrics aside), the } \\
\text { spot takes on the dimensions of an MTV video, and that is why it will be more } \\
\text { memorable to a younger audience" }\end{array}$ \\
\hline 35 & 1983 & $B \& W$ & $\begin{array}{l}\text { Subject: Factors accounting for Kool } \\
\text { volume and share decline }\end{array}$ & $\begin{array}{l}\text { "The brand group hypothesizes that the combination of severe minority } \\
\text { unemployment (particularly youth) and the recent price increases have caused } \\
\text { Kool's volume and share to decline..." "Brands directed at segments most } \\
\text { affected by economic adversity (youth and minorities) were affected } \\
\text { disproportionately." "Important Kool segments - young smokers and blacks..." }\end{array}$ \\
\hline 36 & 1984 & $B \& W$ & $\begin{array}{l}\text { Additional analyses: the national brand } \\
\text { switching studies }\end{array}$ & $\begin{array}{l}\text { Smoking incidence for } 16-25 \text { year olds: "incidence among } 16-25 \text { year olds } \\
\text { rose." Demographics by size of product, includes } 16-25 \text {; brand switching } 16-25 \text {. }\end{array}$ \\
\hline 37 & 1973 & LOR & $\begin{array}{l}\text { Re: Faulkner, Dawkins \& Sullivan } \\
\text { Cigarette Analysis \#MR7590 }\end{array}$ & $\begin{array}{l}\text { States age brand shares would be the same for all companies but for each } \\
\text { company's youth oriented brand (Marlboro, Winston, Kool). Notes tendency of } \\
\text { new products targeted to younger people. Speculates about patterns in coming } \\
\text { decades. Notes, "we all prefer to have a young franchise, and we are working to } \\
\text { accomplish this." }\end{array}$ \\
\hline 38 & 1975 & LOR & $\begin{array}{l}\text { Subject: Progress report-Zack Filter and } \\
\text { Menthol }\end{array}$ & $\begin{array}{l}\text { Quotes retailers as saying "Consumers are young people between } 14 \text { to } 25 \text { years } \\
\text { of age." Advocates the continued use of counter displays, sampling, and new } \\
\text { emphasis on suburban youth. }\end{array}$ \\
\hline 39 & 1975 & LOR & $\begin{array}{l}\text { Lorillard - New products work session: } \\
\text { LPT, DIM next steps }\end{array}$ & $\begin{array}{l}\text { Includes } 2 \text { tables, first table shows Lorillard brands use by age }(21+) \text { and sex for } \\
\text { established and new brands. Holds Marlboro up as an example in "the need to } \\
\text { attract young smokers, particularly young male smokers to the company's total } \\
\text { franchise." Includes discussion of cigarette characteristics inc. attractiveness of } \\
\text { "natural"cigarettes and low-irritation menthols to young smokers. }\end{array}$ \\
\hline 40 & 1977 & LOR & Re: Number of smokers & Includes population estimates for the $14-17$ age group. \\
\hline 41 & 1983 & LOR & [Re: Teenage smoking rates] & $\begin{array}{l}\text { Refers to } 1982 \text { report on survey of high school seniors. States "daily smoking } \\
\text { incidence among this group has remained stable (at } 21 \% \text { ) since } 1980 \text {, moreover, } \\
\text { the } 1982 \text { study confirms a higher start rate currently among girls." Expresses } \\
\text { concern that "because the number of teenagers is declining rapidly, even a stable } \\
\text { smoking incidence would mean a declining number of entering smokers." }\end{array}$ \\
\hline 42 & 1970 & PM & $\begin{array}{l}\text { Suggestions for research to answer } \\
\text { questions based on Philip Morris } \\
\text { behavioral study }\end{array}$ & $\begin{array}{l}\text { "Marlboro has such a high percentage of its smokers among the types of young } \\
\text { people our survey misses out of necessity (on campus college students, those in the } \\
\text { military and those under } 18 \text { years of age)." "There are three groups where smoker } \\
\text { percentages and Marlboro shares need to be checked - college students living on } \\
\text { campus, young people in the } 14-17 \text { age group..." "obtain interviews with those } \\
\text { who appear to be between the ages of } 14 \text { and } 21 . \text {." }\end{array}$ \\
\hline 43 & 1975 & PM & $\begin{array}{l}\text { Subject: The decline in the rate of growth } \\
\text { for Marlboro Red }\end{array}$ & $\begin{array}{l}\text { "Slower growth rate in the number of 15-19 year olds... Most of these (tracking) } \\
\text { studies have been restricted to people age } 18 \text { and over, by my own data, which } \\
\text { includes younger teenagers, shows even higher Marlboro market penetration } \\
\text { among 15-17 year olds." }\end{array}$ \\
\hline 28 & 1981 & PM & $\begin{array}{l}\text { Subject: Young smokers prevalence, } \\
\text { trends, implications and related } \\
\text { demographic trends }\end{array}$ & $\begin{array}{l}\text { "Because we have our highest share index among the youngest smokers, we will } \\
\text { suffer more than the other companies from the decline in the number of teenage } \\
\text { smokers." }\end{array}$ \\
\hline 44 & 1987 & PM & List by year of movies. & $\begin{array}{l}\text { Includes "The Muppet Movie," "Maricela" (awarded Best Children's Script) and } \\
\text { "Who Framed Roger Rabbit?" as movies in which cigarettes brands were placed }\end{array}$ \\
\hline 45 & 1973 & $R J R$ & $\begin{array}{l}\text { Research planning memorandum on } \\
\text { some thoughts about new brands of } \\
\text { cigarettes for the youth market }\end{array}$ & $\begin{array}{l}\text { "Realistically, if our company is to survive and prosper, over the long term, we } \\
\text { must get our share of the youth market." }\end{array}$ \\
\hline 46 & 1973 & RJR & $\begin{array}{l}\text { Subject: Cigarette concept to assure RJR } \\
\text { a larger segment of the youth market }\end{array}$ & $\begin{array}{l}\text { Seeking to develop RIR youth appeal brand: "These new youth appeal cigarettes } \\
\text { for market testing for which the following advertising claims could be } \\
\text { unequivocally proven: they will deliver more flavor, more enjoyment, and more } \\
\text { puffs..." }\end{array}$ \\
\hline 47 & 1974 & RJR & $\begin{array}{l}\text { [Re: What causes smokers to select their } \\
\text { first brand of cigarettes] }\end{array}$ & $\begin{array}{l}\text { "If a person is going to smoke cigarettes, he generally starts during his teens, } \\
\text { primarily to conform with a close friend or friends." }\end{array}$ \\
\hline 22 & 1974 & RJR & 1975 Marketing plans presentation & $\begin{array}{l}\text { "As this } 14-24 \text { age group matures, they will account for a key share of t he total } \\
\text { cigarette volume-for at least the next } 25 \text { years." }\end{array}$ \\
\hline 48 & 1987 & RJR & Subject: Camel's $75^{\text {th }}$ anniversary & Discusses contest-Kids rendering of Old Joe to win RJR bonds. \\
\hline 49 & 1988 & RJR & YAS resource allocation & $\begin{array}{l}\text { "Recommendation: RIR's YAS brands should reach YAS with a dominant } \\
\text { promotion voice in 1989, i.e., at least \$48mm should reach General Market } \\
\text { YAS." "Highest \% YAS participation is in: (1) Direct mail pack offers; (2) In-store } \\
\text { pack offers; (3) Targeted pack sampling/intercept." }\end{array}$ \\
\hline
\end{tabular}


Table 3 Terms associated with young adult marketing

\begin{tabular}{lll}
\hline Term & Meaning & Frequency \\
\hline YAM & Young adult male & 22 \\
YAS & Young adult smoker & 30 \\
FUBYAS & First usual brand young adult smoker & 24 \\
Young Adult & $18-24$ years old-target market & 661 \\
Young Adult & $18-24$ years old-usage behaviour & 79 \\
\hline
\end{tabular}

discusses language used "when discussing the younger adult smoker market."' ${ }^{11}$ The specific terms to be used have been redacted from all copies we were able to locate over the course of this study. However, the memorandum proceeds to "suggest that we all begin using this terminology in our oral communications, both formal and informal".$^{51}$ A later internal memorandum (dated 8 December 1981) instructed RJ Reynolds employees to falsify data collected on underage smokers by reclassifying all those below age 18 as 18 - “[t]he purpose of this memo is to recommend aging all known under 18 year old smokers into the NFO Panel Data at age 18 and classifying them as continuing smokers, with only those smokers new to the business classified as new smokers. This represents maintenance of the current method of tabulation.." ${ }^{22}$

A 1986 document shows that it was standard procedure for the law department at RJ Reynolds to review advertising, promotions, and packaging plans. According to this document, the company policy is that it does not market its products to youth or non-smokers, and the purpose of the legal review of marketing plans was to keep the marketing activities "within acceptable risk parameters". ${ }^{53}$

The term "youth" is rarely seen in documents after 1980, with the exception of documents discussing youth access issues, such as access legislation, prevention programmes, and statements of company policy (that is, "we don't want kids to smoke-smoking is an adult custom"). The terms most often seen in industry documents after 1980 refers to younger smokers as: "young adult smokers" (YAS), "younger adult male smokers" (YAMS), and "first usual brand young adult smokers" (FUBYAS). These terms typically refer to individuals identified as 18-20 years of age. Acronyms associated with these terms, and the frequency of their appearances as target markets within the collection, are included in table 3.

Entering the search string "YAM or YAS or FUBYAS or young adult or young adults" into the search engine for the online collection (http://roswell.tobaccodocuments.org) returned 928 results. The term "young adult" appeared 685 times as "target market", with approximately 540 of these occurrences appearing in documents after 1975. These documents are highly descriptive of an intense effort on the part of all cigarette manufacturers to compete for this market segment. Documents using various forms of "young adult" terms often specify an age range, generally beginning at 18 years and reaching an upper limit of 20,21, 24, or 25 years. However, inconsistencies in the use of these terms are found in a few documents. For example, in January 1990, a division manager for RJ Reynolds issued a memorandum asking sales representatives for the company to identify stores frequented by large numbers of young adults. He specified that "[ $t]$ hese stores can be in close proximity to colleges[,] high schools or areas where there are a large number of young adults frequent[ing] the store.." ${ }^{54}$ The purpose of the exercise was to "try to keep premium items in stores at all times". ${ }^{54}$ In May of the same year, the division manager issued a retraction, stating: "I was wrong in identifying the specific age group of these young adults. It has always been this company's policy that we do not promote or sell our cigarette products to anyone under the age of $21 .^{\prime \prime 55}$ The apology given is not for mistakenly including "high schools" in the original memo, but rather for identifying a "specific age group".

A second example of a document that talks interchangeably about young adult smokers and teenage smoking is a report authored by RJ Reynolds marketing researcher Diane Burrows. This 1984 report entitled "Younger adult smokers: strategies and opportunities", stated the importance of young smokers as follows: "Young adult smokers have been the critical factor in the growth and decline of every major brand and company over the last 50 years. They will continue to be important to brands/companies in the future for two simple reasons: (1) the renewal of the market stems almost entirely from 18 -year-old smokers, no more than $5 \%$ of smokers start after age 24; and (2) the brand loyalty of the 18-year old smokers far outweigh any tendency to switch with age."156 While the report was careful only to mention young adult smokers over the 18 years of age, the report's appendix shows that "more than two-thirds of male smokers start by age 18," suggesting that the term "young adult smoker" is merely a euphemism used to define teenage smokers. ${ }^{57}$

A 1992 document labelled Marlboro Brand Review reports data on the percentage of 16-24 year old smokers in the UK using Marlboro Reds and Marlboro Lights. ${ }^{58}$ This report notes that Marlboro maintains a strong representation among this age group and refers to these younger smokers as "CHIMPSyoung, self confidence, socially active" ${ }^{58}{ }^{58}$

A business plan for Philip Morris USA for the period 1994-98, discusses factors that might impact tobacco sales. ${ }^{59}$ The plan notes that Marlboro is successful because it has a large share of the young adult smoker market. This document discusses how regulations could impede cigarette sales noting specifically that, "young adults' access to tobacco products has become the antismoking movements principal argument in seeking to impose further restrictions on tobacco sales and marketing practicesprimarily vending, self-service, promotions and advertising." ${ }^{59}$ Ironically, it appears that Philip Morris was referring to teenagers when they used the terminology "young adults". Public health campaigns to curtail marketing of cigarettes through restrictions on vending machines and self-service displays have clearly focused on reducing commercial access to tobacco products by minors, not "young adults". ${ }^{60-62}$

A 1991 Philip Morris document also appears to be referring to teenage smokers when discussing the results of survey data evaluating trends in cigarette brand share. This document, "Reasons for considering Camel as a serious competitor", noted that "in the past year, $1.5 \%$ of Camel smokers were new smokers. This represents the second highest new smoker rate in the industry. Camel is outperformed by Newport $(2.2 \%)$, and it is followed by Marlboro (1.2\%)." ${ }^{\prime 3}$ The report includes several charts referring to the age profile of Camel smokers. One of the groups is labelled "YA", but has no age assigned to the label. The "YA" label appears to refer to teenage smokers since the percentage of smokers reporting their usual cigarette brand as Camel was different from all of the adult ( 18 years and older) age groups listed in the table by age, but nearly identical to a federal government survey which estimated the percentage of teenage smokers (age 12-17 years of age) using Camel cigarettes during the same time period. ${ }^{64}$

The acronym FUBYAS (first usual brand young adult smoker) is not consistent with the idea of marketing to adult smokers, since $80 \%$ of smokers have established their first brand by the age of 18 . The observation that most smokers make their initial brand choices during their teenage years was well known to the tobacco industry. For example, a Philip Morris report on smoking trends of young smokers observed, "it is during the teenage years that the initial brand choice is made. At least a part of the success of Marlboro Red during its most rapid growth period was because it became the brand of choice among teenagers who then stuck with it as they grew older." ${ }^{28}$

Entering the search string "FUBYAS" into the search engine for the online collection (http://roswell. 
tobaccodocuments.org) returned 31 industry documents, most of which are from the RJ Reynolds website. A 1989 RJ Reynolds marketing research report discusses the strategic importance of young adult smokers noting that this group represents the only source of replacement smokers and less than one in three start after age $18 .^{56}$ The report indicates that FUBYAS drive the growth of Marlboro and Newport, and that the value of FUBYAS group compounds over time because of brand loyalty and increases in daily cigarette consumption..$^{56}$ The report also outlined strategies to attract FUBYAS by giving a focused YA message, recommending sampling and field marketing that impacts peer pressure. ${ }^{56}$

\section{Features of tobacco product marketing geared to new smokers}

The number and variety of industry marketing research studies found on each company's websites suggests that nothing in the marketing process was left to chance. We found elaborate studies documenting large population surveys tracking brand preferences and small scale focused studies intended to gain insight into the psychological dynamics of consumers or their preferences for product style and packaging. The often cited "four Ps" of marketing-product, price, promotion, and placement-offer a useful organising framework for reviewing the marketing strategies of the tobacco companies as applied to the youth segment. ${ }^{65}$

\section{Product}

Within the "Roswell Park Youth and Marketing Collection" we identified 22 documents assigned the minor subject heading "Product-Youth," and 313 assigned "Product-Development" which indicates that cigarette manufacturers recognised that tobacco product design features are important to consider in marketing to young smokers. As early as the 1940s the industry recognised through market research that certain features of cigarettes appealed to younger smokers. An analysis of successful first brand strategies conducted by RJ Reynolds attributed Pall Mall's success with young smokers in the 1940s and 1950s to the brand's promise of mildness because of the product's longer length. ${ }^{57}$ In the 1950s and 1960s, the success of filtered brand cigarettes, such as Marlboro and Winston, was attributed to the perception among young smokers that filters made cigarette smoke milder. ${ }^{57}$ Statements from documents written at both RJ Reynolds ${ }^{66}{ }^{67}$ and Philip Morris ${ }^{68}$ recognised the specific characteristics of a cigarette such as the filter were preferred by a majority of both high school and college students.

Market research conducted by Philip Morris in 1959 noted that young smokers could be won with mildness: "people want mildness ... .we also should win more young nonsmokers with mildness." ${ }^{\prime 68}$ In the early 1960s, cigarette manufacturers recognised that brands featuring filters were the most popular brands among young smokers as illustrated by the following statements "Winston [was] apparently . . .the most popular brand with high school students." ${ }^{16}$ The same document cites Salem as being "much more popular with high school and college girls than with boys." ${ }^{69}$

According to a 1981 RJ Reynolds document, Philip Morris began using ammoniated sheet material in their cigarettes in 1965, and "increased the use of the sheet periodically from 1965 to $1974 . .^{\prime 70}$ It states that "[t]his time period corresponds to the dramatic sales increase Philip Morris made from 1965 to 1974." ${ }^{60}$ The Reynolds report also notes quality improvements and increased sales performance in each instance indicating that the ammoniated sheet process led to products that had "milder, smoother taste . . .higher smoke $\mathrm{pH}$. . . positive flavor without negative burley characteristics . . .cleaner taste with more free nicotine, and stronger physiological impact with less harshness." ${ }^{\prime 70}$ The control over smoke $\mathrm{pH}$ allowed by ammoniation was cited in a RJ Reynolds document from 1973 as a strong factor in the success of the Marlboro brand..$^{71}$ It notes that $\mathrm{pH}$, sugar, free nicotine, and ammonia content of Marlboro and Kool had favourably affected the performance of these brands against Winston and Salem. RJ Reynolds followed Philip Morris using ammoniated sheet material in their products, introducing it in Camel Filters in 1974 and Winston Kings in 1979. The documents note quality improvements and increased sales performance in each instance. ${ }^{70-72}$

In a 1969 report RJR's Claude Teague proposed a formula that measured an individual's "propensity to smoke". ${ }^{66}$ This formula was expressed as follows:

$$
P=(H+G)-(C+R)
$$

where $\mathrm{P}=$ propensity to smoke; $\mathrm{H}=$ nicotine habituation factor; $\mathrm{G}=$ gratification factor; $\mathrm{C}=$ cost factor; and $\mathrm{R}=$ government regulatory factor.

According to Teague, this formula needed to eliminate the habituation factor to accurately express a "pre-smoker's" propensity to smoke, since pre-smokers were, by definition, not habituated. This left " $\mathrm{G}$ ", or "gratification", as the sole positive factor in determining the propensity for the pre-smoker to begin smoking. ${ }^{66}$ Subsequent industry research in the early 1970s focused on ways to meet the gratification needs of the young smokers, including the addition of flavours to cigarettes. For example, in 1972, Brown \& Williamson reviewed new concepts for a youth cigarette including cola flavour, apple flavour, and a sweet flavour stating: "[I]t's a well-known fact that teenagers like sweet products. Honey might be considered." ${ }^{73}$ The same year, RJ Reynolds was speculating about a product that could target competitive brands, namely, Marlboro and Kool, that have "exhibited exceptional strength in the under 35 age group, especially in the 14-20 age group" with a "product strategically targeted at this group [that] would complement our current product line". ${ }^{74}$ One suggestion in the memo included an "apple wine cigarette" owing to the "growing popularity of fruit wines among young adults $18-25^{\prime \prime}{ }^{74}$

Another RJ Reynolds report by Teague in 1973 discusses the importance of product features in successfully capturing a share of the youth smoking market. "Realistically, if our company is to survive and prosper, over the long term, we must get our share of the youth market: In my opinion this will require new brands tailored to the youth market; I believe it unrealistic to expect that existing brands identified with an over-thirty 'establishment' market can ever become the 'in' product. Thus we need new brands designed to be particularly attractive to the young smoker, while ideally at the same time being appealing to all smokers" ${ }^{45}$ Teague identified the following specific characteristics to be used in developing new brands tailored to the youth market: (a) nicotine level of 1.0-1.3 mg/cigarette; (b) $\mathrm{pH}$ level of the smoke delivered at a level (5.8 to 6.0) to insure slow absorption of nicotine; (c) tar content of 12-14 mg/ cigarette to achieve the desired taste and visible smoke; (d) bland smoke to address low tolerance for smoke irritation of beginning smoker; (e) $100 \mathrm{~mm}$ length to facilitate lighting; and (f) a reasonably firm rod. ${ }^{45}$ A 1974 summary of a meeting held at RJ Reynolds, in which Teague is listed among the participants, discussed cigarettes designed for beginning smokers, noting that such a cigarette should be "low in irritation and possibly contain added flavors to make it easier for those who never smoked before to acquire the taste of it more quickly". ${ }^{75}$

By the early 1970s, Philip Morris' Marlboro brand had become the dominant youth cigarette, and the other tobacco companies began to focus efforts on competing with Marlboro for market share. ${ }^{4676}$ For example, one British American Tobacco (BAT) memorandum commented that Marlboro was "the single biggest threat to BAT's number 1 position. No one brand can destroy Marlboro". ${ }^{77}$ The memorandum recommends a " . . major effort behind one brand aimed at starters/ young adults". ${ }^{77}$ A 1975 RJ Reynolds report observed that "the 
$85 \mathrm{~mm}$ Normal Flavor Filter was the preferred category of cigarettes among youth". ${ }^{78}$ This report comments that "the 14-24 age group" would "account for key share of cigarette volume for the next 25 years" as they matured. ${ }^{78}$

With the advent of "light" cigarettes, the "mild" flavoured, high filtration, light cigarette would become the standard "youth starter" cigarette by the late 1970s, and has remained so through the 1990s. Philip Morris' Marlboro Lights has dominated the youth market segment since the early 1970s, and the rest of the industry endeavoured to create "youth brands" by copying the physical characteristics of this brand in order to gain market share. RJ Reynolds concluded that one of the strengths of Marlboro over Winston among young smokers was the perception that "Marlboro was smoother than Winston, and less strong". ${ }^{57}$ Marketing experts at RJ Reynolds recommended that "RJR should use copy strategies which emphasize product positives to younger adult smokers. Connotations of 'weak', 'concerned', or 'low tar', should be avoided and elements of 'mild', 'smooth', 'rich', 'smoking pleasure' should be emphasized." ${ }^{57}$

Documents immediately predating the introduction of the "Joe Camel" campaign discuss giving "high priority to eliminating elements of harshness from its younger-adult-targeted products" ${ }^{79} 80$ The Joe Camel advertising campaign emphasised "smoking pleasure" and "smooth taste" ${ }^{81}{ }^{82}$ The paper by Wayne and Connolly in this issue describes the research programmes implemented by RJ Reynolds in the 1980s and 1990s to reformulate Camel cigarettes so it would be perceived by smokers as milder and less harsh tasting and could further broaden Camel's user base, particularly among beginning smokers who were opting for Marlboro. ${ }^{82}$ Lorillard introduced its "Harley-Davidson" cigarette brand in the 1990s also to compete with Marlboro. In 1996, Lorillard introduced "Harley Light 85 's" designed specifically to "improve the products overall acceptability and satisfaction among young smokers and to be more like Marlboro Lights $85^{\prime \prime} .^{83}$

\section{Price}

It is well established that pricing is an important factor influencing demand for tobacco products. Some evidence suggests that as a group, teenagers are more responsive to variations in tobacco product pricing. ${ }^{60}$ Within the "Roswell Park Youth and Marketing Collection", 113 documents were assigned the minor subject heading "Advertising and Marketing-Pricing", and 37 were assigned "Youth $(<18$ years old $)$-Price elasticity". The paper by Chaloupka and colleagues in this issue examines industry documents describing on how cigarette pricing impacts consumption patterns. ${ }^{84}$ The most explicit references to underage smokers come from memoranda and reports written by or sent to Myron Johnson, an economist at Philip Morris. ${ }^{28385}$ Johnson studied demographic and economic factors that might influence future trends in the sale of Philip Morris' cigarettes. In 1975, he reported that “Marlboro's phenomenal growth rate in the past has been attributable in large part to our high market penetration among young smokers ...15 to 19 years old ... my own data, which includes younger teenagers, shows even higher Marlboro market penetration among 15-17-year-olds." ${ }^{43}$

In a 1981 memorandum, Myron Johnston acknowledges that the effect of a price increase in cigarettes would vary for different segments of the population: "Many of us have hypothesized that price elasticities are different for different demographic or socioeconomic groups, e.g., that price increases would have less effect on the higher income groups and on the older and therefore more habituated smokers, than on other smokers." ${ }^{186}$ In a subsequent memorandum, Johnson comments how a price increase in the cost of a pack of cigarettes would have an especially large impact on teenage smokers and Marlboro sales: "[w]e will no longer be able to rely on a rapidly increasing pool of teenagers from which to replace smokers through lost normal attrition ... Because of our high share of the market among the youngest smokers Philip Morris will suffer more than the other companies from the decline in the number of teenage smokers." ${ }^{28}$ In a 1981 report authored by Murray Daniel, he commented on how the gasoline shortage in the late 1970s had contributed to the declining trend in teenage smoking prevalence: "I think it is more than coincidental that the sharpest declines in smoking prevalence among teenage males occurred in 1979 and 1980, the years in which the price of gasoline rose most sharply. When it comes to a choice between smoking cigarettes or cruising around in his car, the average teenage male would probably choose the latter." ${ }^{85}$

Documents produced by RJ Reynolds reveal similar findings. ${ }^{57}{ }^{87}$ A 1984 RJ Reynolds report also highlights the importance of price as a factor influencing cigarettes sales to young smokers. The report notes: “[s]ome evidence suggests that younger adult smokers are interested in price, but unlikely to adopt a brand whose only hook is price." ${ }^{\prime 56}$ The report goes on to recommend that "a price value brand would need a conspicuous second 'hook' to reduce possible conflict between younger adults' value wants and imagery wants. The most suitable 'hooks' are likely to be based on product quality, since these provide easy-to-explain public reasons for switching. Tactically, extended periods of closely targeted pack promotions (BlGlF [that is, buy one, get one free] sampling) in selected sites (e.g., convenience stores, military exchanges, special events) could lead to brand loyalty from repeated trial. This should be considered an investment program." ${ }^{57}$

Philip Morris' decision to slash the price of its popular premium brand cigarettes in 1993 (that is, Marlboro Friday), coupled with an increased emphasis on value added promotions, helped fuel a resurgence of youth smoking in the 1990s. ${ }^{88-90}$

\section{Advertising and promotions}

Pollay, a marketing professor at the University of British Columbia, has reviewed industry documents produced in Canadian tobacco litigation on the subject of marketing to youth. ${ }^{11}$ He found that the tobacco manufacturers carefully and extensively researched the process of conceiving, developing, and deploying cigarette advertising targeted to youth. To recruit starters, brand images communicated independence, freedom, and peer acceptance and advertising portraying smokers as attractive, autonomous, accepted and admired, and athletic. According to Pollay, the industry's documents he reviewed demonstrated that their cigarette advertising influenced demand for cigarettes, not just brand loyalty and brand switching as the tobacco industry has asserted. ${ }^{11}$

We have also uncovered many corporate documents from US tobacco manufacturers that make reference to brand imagery as a critical factor in the success of a given brand with young smokers. For example, a 1984 RJ Reynolds document attributed the success of Marlboro to its strong imagery that "was in tune with younger adult smokers' enduring want to express their maturity and independence through smoking." ${ }^{157}$ The success of Winston as a brand popular with young people in the 1960s was attributed to "peer pressure-the "bandwagon effect"'. ${ }^{57}$ A 1973 RJ Reynolds document outlined the advertising elements of a brand that would attract young smokers as including "participation, togetherness and membership in a group ... a mechanism for relieving stress, tension, awkwardness, boredom . . . adventurous, different, adult . . . something arousing, some curiosity and some challenge ... must become the proprietary 'in' thing . . .should not be perceived as a 'health' brand." ${ }^{45}$

Teens aged 16 and 17 have especially strong social ties to friends. ${ }^{91}$ Thus, advertising which reinforces how a product will contribute to acceptance by one's peers would be expected to be especially effective with teenagers. We uncovered several 
examples of marketing plans stressing social acceptance as a central theme of the advertising. For example, a 1984 marketing research report by RJ Reynolds commented that: "[g]iven younger adult smokers' keen interest in peer acceptance/ approval, it is likely that younger adult smokers would be interested in a brand which effectively addresses social acceptability and also provides the other smoking benefits they want." ${ }^{\prime 57}$ This report recommended that RJ Reynolds "make resources available to develop/improve its capabilities to thoroughly identify and track demographics, values/wants, media effectiveness, and brand performance within sectors of the younger adult smoker population." ${ }^{157}$

The results of such an investment in market research appears in documents beginning in the mid-1980s which refer to studies on younger adult smoker perceptions of Camel cigarettes. A 1984 memorandum analysing young adult perceptions of Camel recommended that advertising for Camel "be positioned against young adult smokers who would like to be non-conformist". ${ }^{22}$ This memorandum includes a table of FUBYAS social groups, including such labels as "Goodies", "Preps", "Rockers", and "Punkers". Camel is defined as appealing to "Rockers", "Party Partiers", and "Punkers". ${ }^{92}$ A 1986 memo recommends that Camel advertising be directed toward using peer acceptance/influence to provide the motivation for target smokers (defined as 18-24 male smokers) to select Camel. ${ }^{93}$ The memo suggests that the objective the advertising be to convince "target smokers that by selecting Camel as their usual brand they will project an image that will enhance their acceptance among their peers." ${ }^{\prime 93}$ The memo notes that, "advertising will rely on clearly aspirational appeals (the me I want to be versus the me I am) to provide the motivation for target smokers to select Camel." ${ }^{\prime 93}$

Cigarette companies have utilised a wide range of promotional strategies such as sampling, use of discount coupons, sponsorship of events, point-of-sale incentives (for example, buy one get one free, posters, lighters, $\mathrm{T}$ shirts), contests, and media delivered advertising (TV and movie product placements) to promote and maintain brand sales. Tobacco manufacturers have fastidiously held to the position that these promotional efforts are aimed at established adult smokers, with the goal of capturing potential "brand-switchers". However, the public health literature has clearly demonstrated that youth are aware of and participating in a wide variety of tobacco brand promotions, and that there is a consequent adverse effect upon adolescent smoking behaviour. ${ }^{12-16} 90$ The paper by Katz and Lavack in this supplement examines the industry's use of bar promotions to market cigarettes. ${ }^{94}$ While one might expect that bar promotions would have no impact on teenage smokers, tobacco industry documents reveal that such promotions help communicate product brand information indirectly through a diffusion process. ${ }^{94}$ Since teens aspire to be older and more mature than they are, recruiting younger adults to smoke your cigarette brand is perhaps the best way to try to communicate to teens that your brand is the "in brand". ${ }^{91}$

Within the "Roswell Park Youth and Marketing Collection" a total of 477 documents were coded with "Advertising and Marketing-Promotional item/program". As the size of this subset suggests, promotional item giveaways appear to play a large role in the marketing activities of the tobacco companies. For example, during the 1970s and 1980s Philip Morris sponsored the "Marlboro Resort Program" which described promotional activities geared to the younger smoker during spring break, summer vacations, and Christmas breaks in places like Fort Lauderdale and Daytona Beach. ${ }^{95-99}$ The rationale for the programme was based on the observation that "vacationers (who are young adults) are 'ideal candidates for Marlboro"". 95 This report describes the "Marlboro Resort Program" as including promotional materials such as posters, mass sampling, store sales with offers for free Marlboro towels or T shirts, and point-of-sale incentives.

In the 1990s, Philip Morris sponsored the "Marlboro Adventure Team," which had the stated goal to "increase vis- ibility and build Marlboro sales". ${ }^{100}{ }^{101}$ While many of the items offered as part of this promotional programme would appear to have a youthful appeal, Philip Morris required participants to provide their age and signature, with the disclaimer that "individuals must be 21 years of age or older" to participate. However, we found letters from parents sent to Philip Morris insisting that the names of their underage children be removed from the company's mailing list. ${ }^{102}$ This indicates that Philip Morris was at least aware that the promotional programme was attracting the attention of (and responses from) underage consumers.

We uncovered many documents describing programs for cigarette sampling. Many of these documents indicate that sampling activities are restricted to smokers 21 and older. However, despite such statements, the locations selected for sampling often corresponded to places where young people would be expected to congregate, such as rock concerts, sporting events, recreational areas, and shopping malls. ${ }^{22} 495^{54} 95-101$ 103-106 Combining sampling activities with event sponsorships offered the opportunity to distribute promotional items, to both sell and to sample (that is, distribute freely), and to collect marketing data from attendees. Additionally, event sponsorship provided the opportunity to extend exposure of the brand name and/or logo when the event itself is advertised, discussed or reported on in the media, or televised. ${ }^{107}$

Sponsorship of sporting events was especially popular with the cigarette industry since it gave them a vehicle to link their products with popular events and an opportunity to get their brand logos on television in violation of the spirit of the federal broadcast advertising ban. A 1987 Philip Morris discusses the value of sponsorship of auto racing: "Marlboro 500 at Michigan International Speedway was highly successful in creating brand awareness and generating positive publicity. The PM sales force did and exceptional job in placing banners and P.O.S. [point of sale] material in the surrounding area, as well as conducting sampling activities at the track itself. The race was broadcast live on ABC-TV, and Marlboro signage was visible throughout the 4 hour telecast." ${ }^{108}$

\section{Placement}

Within the "Roswell Park Youth and Marketing Collection", a total of 69 documents were coded as "Advertising and Marketing-Product placement." Product placement refers, in this coding, to the location where tobacco products are offered for sale and the placement of product advertising. Many of the documents we found revealed a strategic interest in placing youth oriented brands, promotions, and advertising in locations where young people congregate. 22 49 54 95-101 103-106 For example, a 1973 Winston Box Marketing Plan, prepared by William Esty Agency for RJ Reynolds, outlined strategies for targeting of Marlboro Box smokers in certain markets, including the metro Los Angeles test area. The target audience was defined as "young, affluent, urban male, age 14-20, who comprise majority of box smokers". ${ }^{105}$ The report outlines a media plan, including schedule and budget for newspaper (sports section), magazine, out-of-home, point of sale, and promotional item methods, including "use of self-service displays in retail locating accessible to and trafficked by the target". ${ }^{105} \mathrm{~A}$ 1984 Philip Morris report reviewing possible locations for the "Marlboro Spring Vacation Program", whose goal was to select places where young adults congregate. The report describes ski resorts and 98 different beach locations. ${ }^{99}$ We also located two instances in the 1990s where RJ Reynolds sales reps were instructed to identify high volume cigarette outlets in close proximity to colleges and high schools where large numbers of young adults are likely to frequent. ${ }^{54} 106$

The paper by Mekemson and Glantz in this supplement examines how the tobacco industry promotes smoking through entertainment media. ${ }^{109}$ In our analysis of documents 
pertaining to marketing to youth, we identified several post-1971 industry documents on product placements in films, articles on celebrities smoking, and the encouragement of smoking on television. A 1972 letter from Beverly Walker of Universal Pictures to RJ Reynolds expressed interest in the use of Camel and/or Winston radio commercials from 1962 for use in the film American Graffiti. ${ }^{110}$ The author of the letter explains that the films' plot focuses on a group of teenagers on the cusp of adulthood and notes that "the value of this type of subliminal advertising is known and accepted by now". ${ }^{110} \mathrm{~A}$ letter dated October 1979 from Dovemead Limited to Philips Morris Europe discusses the placement of Marlboro brand name in the movie Superman II. ${ }^{111}$ The letter notes that the Marlboro brand name will be shown on a billboard in a major scene and outlines the monetary and discretionary specifics of agreement. A 1983 internal Brown \& Williamson memorandum discusses the "Kool record continuity promotional concept" suggesting that programme be tied-in with the RCA record club and offer records at $50 \%$ discount. ${ }^{112}$ The memorandum explains that "smokers can order from a special Kool catalog and imagines that this will reach the Kool target audience, with the benefit of possible tie-ins such as MTV". ${ }^{112}$ We located documents from 1983 describing an agreement between Associated Film Promotions and Sylvester Stallone guaranteeing use of Brown \& Williamson products in no less than five movies for a payment of $\$ 500,000 .{ }^{113}$ A subsequent Brown \& Williamson document describes the items purchased (jewellery, car, etc) for product placements in "Where The Boys Are", "Killing Ground", and "Sylvester Stallone movies". ${ }^{114}$ We also found a 1989 document listing Philip Morris schedule of product placements for 1987-89. ${ }^{44}$ This document provides a list of movie titles, the products supplied to the movie producer, and estimated fair market value of the advertising gained from the product placement. Products supplied include cigarettes, signage, neon and period signage. Movie titles included "The Muppet Movie", "Amazon Women on the Moon", "Robocop", "Tapeheads", "Dream Team", "Field of Dreams", "K-9", "War Party", "Who Framed Roger Rabbit", and "Crocodile Dundee". ${ }^{44}$

\section{DISCUSSION}

The results from this study reveal that the cigarette manufacturers have competed vigorously against each other over the last 50 years to capture a share of the youth market. Despite the industry's public assertion that its marketing efforts were only aimed at brand loyalty and switching, their own documents contradict this claim. The documents show that each of the tobacco companies carefully researched and knowingly implemented marketing strategies to appeal to young smokers. Before the mid 1970s industry documents are fairly explicit in discussing the need and desirability of capturing a share of the teenage smoker market. Later industry documents talk about FUBYAS, beginning smokers, starter smokers, and young adults smokers, without mentioning teenagers explicitly. However, merely changing the language used to refer to teenage smokers does not alter the underlying economic reality that requires companies to capture a share of the starter market, most of whom are known to be teenagers, in order to prosper. As stated in the marketing plans for Marlboro, the goal was to "attract young adult smokers and retain them as they age". ${ }^{115}$ Ironically, dropping the reference to teenagers as the target audience for a particular brand would actually be perceived positively by older teens (16-17 years old), who dislike being referred to as "teenagers", and instead prefer to be referred to as "young adults". ${ }^{91}$ Marketing research indicates that older teens are not attracted to products that are explicitly marketed to teens. ${ }^{91}$ Thus, the tobacco industry's suggestion that tobacco products are for young adults smokers actually makes cigarettes more appealing to teenagers.
While this study carefully attempted to research the tobacco industry's claim that they have not been interested in recruiting young people to smoke, our ability to understand the marketing practices of the industry is limited to the materials present on industry' websites. We were only able to examine the documents that the tobacco companies turned over through litigation. We do not have access to material that has been withheld, destroyed, or is in the possession of non-tobacco companies such as advertising and consulting firms. In other words, we do not know what we do not have, and probably never will.

Nonetheless, we have uncovered evidence that suggests that relevant documents may have been destroyed. A 1991 fax from a New York marketing firm to RJ Reynolds refers to an attached list of focus groups and market research material on the "Joe Camel" campaign noting "under our current scrutiny, a wise move to rid ourselves of developmental work!". ${ }^{116}$ We also learned that with regards to the youth marketing issue, the language used in documents, especially those from the most recent decades has been sanitised. ${ }^{50}{ }^{51}$ Despite what the tobacco industry may have written or said about not wanting youth to smoke, their actions have suggested otherwise. ${ }^{62117118}$ For example, in the mid 1980s, the Camel ad campaign featured Bob Beck, the Indiana Jones style safari suited adventurer, who was intended to project an image that would appeal to young males. When this campaign was dropped in 1987, it was replaced with the infamous cartoon Joe Camel campaign, hardly evidence of movement towards an adult market segment.

The recent proliferation of cigarette brands touting cooler, smoother, and milder tasting smoke suggests that cigarette companies are still competing to capture a share of the youth smoking segment. Previous research has shown a strong preference for smoking menthol cigarette brands by African American teenagers. ${ }^{119}$ In 1999, Philip Morris introduced a new menthol brand, Marlboro Mild, targeting younger African American smokers. ${ }^{120}$ A recent report on the smoking habits of 9th grade students in Erie County, New York observed a major increase between 1996 and 2000 (from 8\% to 28\%) in the percentage of African American teenagers who reported smoking Marlboro. ${ }^{121}$ Is the recent increase in Marlboro's share of market among African American teenagers in Erie County, New York merely a coincidence or some unintended side effect of marketing to adult smokers? The sheer volume of marketing research performed by cigarette companies on virtually all aspects their products, suggests that unforeseen effects of their marketing efforts (such as teenagers being attracted to purchasing their brand) are unlikely.

The industry documents reviewed in this study validate some "tried and true" prevention strategies and suggest new approaches for discouraging cigarette smoking by young people.$^{60}$ Number one among the "tried and true" prevention approaches is keeping the price of the product high. The industry documents acknowledge that young people are sensitive to variations in the price of cigarettes. ${ }^{57}{ }^{85}$ Increasing the cost of tobacco products (both monetarily and psychologically in terms of time and effort to acquire cigarettes) discourages smoking. The documents also reveal that young smokers primarily select a brand because of its image, not price..$^{2834557}$ Thus, while young smokers are price sensitive, they tend not to want to substitute a premium (image oriented) brand for one whose main feature is its low price. To help reduce the conflict young smokers experience between price and imagery, tobacco companies have devised marketing strategies to add value to the higher priced premium brands that teenagers want. ${ }^{89} 90$ These strategies have include promotions like such as buy one pack, get one free ("BlGlF"), the offer of gifts in return for used cigarettes packs, and packaging cigarettes into smaller more, affordable units (that is, 10 cigarettes per pack instead of 20). ${ }^{57}{ }^{87}$ Presumably, restricting these types of marketing approaches would help discourage young people from smoking. ${ }^{84}$ 
The tobacco documents also provide support for ongoing efforts to limit the way that tobacco products are advertised and promoted. Placing strict limits on where cigarettes are sold and advertised is an obvious approach to discouraging smoking among young people. Product placements and advertising should be kept away from schools and other areas with a high volume of youth traffic. Convenience stores and gas stations are the main commercial outlets where underage smokers purchase cigarettes. ${ }^{61}{ }^{122}$ Communities should consider enacting zoning restrictions to limit the number of tobacco selling outlets. It is likely that the density of tobacco selling outlets impacts the price of cigarettes (that is, more outlets lower prices because of competition).

The tobacco industry's market research reveals that advertising and promotional efforts that associate a brand with images of autonomy, togetherness, risk taking, and social acceptance, make the brand more attractive to young people. ${ }^{56}$ Review of cigarette advertising and promotional activities by an independent board with authority to eliminate elements of marketing that make cigarette smoking attractive to young people should be required of all tobacco companies. To date, the tobacco industry has opposed such a review process. ${ }^{123}$ The marketing documents of the cigarette manufacturers themselves make it clear that it is unable to regulate themselves when it comes to restricting its marketing to the youth segment. ${ }^{62117} 118$

The industry documents also provide evidence for some new approaches to youth smoking prevention. This study has uncovered evidence that product design features such as the package style and colour, the length and diameter of the cigarette, and the use of additives to make the smoke less harsh (that is, milder and smoother) are deliberately manipulated to make a product more appealing to young "starter" smokers. ${ }^{45} 74$ The implication of this finding is that product design features such as the length of the product, its filter, the burn rate and temperature, ingredients and smoke chemistry ( $\mathrm{pH}$ level of the smoke) should be carefully evaluated and regulated in ways that make cigarette smoke less palatable to the new smoker (that is, smoke that is not so easy to inhale). Adoption of prominent graphic warning labels such as those now required on packages of Canadian cigarettes would serve the duel purpose of helping to educate consumers about the risks of smoking while at the same time making the cigarette pack less appealing to younger smokers. ${ }^{124}$ Research in social psychology provides theoretical and empirical justification for the use of vivid photographs in warning labels. ${ }^{125}$ Alternatively, cigarettes could be packaged in identical plain packaging which research suggests would make cigarette smoking less appealing to younger smokers. ${ }^{126}$

In a recent survey of adult smokers, Slovic found that most respondents said that they would not start smoking if they had to it do over again. ${ }^{127}$ The tobacco industry has exploited the fact that adolescents are not in a position to make an informed and rational choice about smoking. Adolescent decisions to engage in risky behaviours, including tobacco use, reflect a distinctive focus on short term benefits and an accompanying tendency to discount long term risks or dangers, and to believe that those risks can be controlled by personal choice. ${ }^{928}$

Studies of teenage smoking patterns also show a tendency among adolescents who have begun to smoke to discount long term health risks. ${ }^{9}{ }^{127} 128$ A recent survey of adult smokers found that while most are aware that smoking is associated with an increased risk of disease, few believe that this risk applies to themselves since they optimistically assume that they will stop smoking before experiencing health problems. ${ }^{129}$ This observation is reinforced in a report prepared for Imperial Tobacco Limited (a Canadian tobacco manufacturer affiliated with British American Tobacco), which examined the smoking attitudes and habits of teenager smokers. The report notes: "[s]tarters no longer disbelieve the dangers of smoking, but they almost universally assume these

\section{What this paper adds}

The vast majority of smokers begin their smoking careers as teenagers. Teenage smokers smoke the most heavily advertised cigarette brands. Brand loyalties are usually established during the teenage years with relatively few smokers switching brands annually. Despite this evidence, cigarette manufacturers claim that they do not want minors to smoke and that their marketing activities are aimed only at established adult smoker.

This paper describes results from a systematic analysis of thousands of previously secret tobacco industry documents to evaluate the claim that the tobacco industry has no interest in marketing its products to youth. The results from this study reveal an undeniable interest on the part of the tobacco industry in marketing cigarettes to minors. In an effort to compete for a share of the starter smoker market, cigarette companies have created special product formulations, developed unique packaging designs and pricing schemes, and developed advertising and promotional campaigns so to appeal to the unique wants and needs of the young smoker. The industry documents provide evidence to support the following approaches to tobacco prevention: (1) keep the price of the product high; (2) keep product placements and advertising away from schools and other areas with a high volume of youth traffic; (3) make cigarette advertising (that is, themes and visual images) unappealing to youth; (4) make product packaging unappealing to youth; and (5) design the product so it is not easy to inhale.

risks will not apply to themselves because they will not become addicted." 130 The report also comments on the fact that teenage smokers rapidly learn how difficult it is to stop smoking once they start smoking regularly: "[o]nce addiction does take place, it becomes necessary for the smoker to make peace with the accepted hazards. This is done by a wide range of rationalizations ... The desire to quit seems to come earlier now than before, even prior to the end of high school. In fact, it often seems to take hold as soon as the recent starter admits to himself that he is hooked on smoking. However, the desire to quit and actually carrying it out are two quite different things, as the would-be quitter soon learns."'130

Once smokers discover that it is not so easy to stop smoking, they begin to develop a wide range of rationalisations to support their continued smoking behaviour. ${ }^{128}$ As described in the paper by Pollay and Dewhirst in this supplement, the tobacco industry is waiting and ready to support these rationalisations with a wide array of new products (for example, filtered cigarettes, low tar, no additives) providing the illusion of a less hazardous cigarette. ${ }^{131}$ The tobacco industry documents provide a unique source of data upon which to design a new generation of prevention and control strategies. The only question that remains is whether public health practitioners will be able to utilise the knowledge gained from those directly involved in marketing tobacco products to reverse the outcome.

\section{ACKNOWLEDGMENTS}

The research described in this paper was supported by grants from the National Cancer Institute CA77021-03, CA87696-01, and by Core Grant CA16056-26.

\section{Authors' affiliations}

K M Cummings, C P Morley, J K Horan, C Steger, Department of Cancer Prevention, Epidemiology \& Biostatistics, Roswell Park Cancer Institute, Buffalo, New York, USA

N-R Leavell, Summerland Communications, Buffalo, New York, USA 


\section{REFERENCES}

1 Cummings KM, Leavell N. Preventing youth smoking. Presentation at the American Public Health Association Annual Meeting; Chicago, Illinois. November 1999.

2 See the testimony of Lynn Beasley VP for Marketing at RJR in the Minnesota tobacco litigation. April 20, 1998 and the testimony of James Morgan, former CEO of Philip Morris Tobacco Company in the Minnesota tobacco litigation. April 22, 1998, in Youth and Marketing Collection linked through URL: http://roswell.tobaccodocuments.org

3 Hill and Knowlton. Cigarette manufacturers announce advertising code. [press release] Brown \& Williamson Tobacco Company, Inc. April 27 1964. Access date: August 21, 2001. Bates No. 690000045-690000047. URL: http://www.bw.aalatg.com/public.asp.

4 Philip Morris. Action against access [advertisement]. Roll call June 29, 1995, page 12.

5 National Association of Attorneys General. Multi-state settlement with the tobacco industry. Boston: Tobacco Control Resource Center, Tobacco Products Liability Project, 2000.

6 Philip Morris to stop ads in magazines read by youth. New York Times. June 6, 2000:C27

7 Tobacco Institute. In the public interest: three decades of initiatives by a responsible cigarette industry." Tobacco Institute. July 10, 1985. Access date: August 21, 2001. Bates No. TIMN0350666- TIMN03506671. URL: http://www.tobaccoinstitute.com.

8 Tobacco Update. Cigarette industry initiatives against youth smoking Tobacco Institute. 1990. Access date: August 21, 2001. Bates No. TIMN0325834 - TIMN0325835. URL: http://

www tobaccoinstitute.com

9 Lynch BS, Bonnie RJ. Growing up tobacco free. Washington DC: National Academy Press, 1994

10 Cummings $K M$, Hyland $A$, Lewit $E$, et al. Discrepancies in cigarette brand sales and adult market share: are new teen smokers filling the gap? Tobacco Control 1997;6(suppl 2):S38-43

11 Pollay RW. Targeting youth and concerned smokers: evidence from Canadian tobacco industry documents. Tobacco Control 2000;9:136-47.

12 Pierce JP, Choi WS, Gilpin EA, et al. Tobacco industry promotion of cigarettes and adolescent smoking. JAMA 1998;279:511-15.

13 Distefan JM, Gilpin EA, Sargent JD, et al. Do movie stars encourage adolescents to start smoking? Evidence from California. Prev Med 1999;28: 1-11

14 King C III, Siegel M. Brand-specific cigarette advertising in magazines in relation to youth and young adult readership, 1986-1994. Nicotine Tob Res 1999;1:331-40.

15 Sargent JD, Dalton $M$, Beach $M$, et al. Effect of cigarette promotions on smoking uptake among adolescents. Prev Med 2000;30:320-27.

16 Pollay RW, Siddarth S, Siegel M, et al. The last straw? Cigarette advertising and realized market shares among youths and adults, 1979-1993. Journal of Marketing 1996;60:1-16

17 Malone RE, Balbach ED. Tobacco industry documents: treasure trove or quagmire? Tobacco Control 2000:9:334-8.

18 http://www.cdc.gov/tobacco/industrydocs/4babout.htm September 18, 2001.

19 http://www.library.ucsf.edu/tobacco/searching.html. September 17, 2001

20 Balbach ED, Gasior RI, Barbeau EM. Evaluating the comparability of searching tobacco industry documents at the Minnesota Depository vs. tobacco industry websites. Tobacco Control (in press).

$21 \mathrm{http}: / / \mathrm{www} . \mathrm{cdc} . \mathrm{gov} / \mathrm{tobacco} /$ industrydocs/glossary. htm. September 18,2001

22 R J Reynolds Tobacco Co. 1975 Marketing Plans Presentation. September 30, 1974. R J Reynolds Tobacco Company, Inc. Access date: August 17, 2001. Bates No. 500746950-500746975. URL: http://www.rirtdocs.com. Continued in: R J Reynolds Tobacco Co. Marketing Objective 1975. Reestablish Our Share of Market. Growth in the Domestic Cigarette Industry. 1975. R J Reynolds Tobacco Company, Inc. Access date: August 17, 2001. Bates No. 500746977-500747019. URL: http://www.rirtdocs.com

23 Achey TL. Subject: Product Information. August 30, 1978. Lorillard Tobacco Company, Inc. Access date: August 21, 2001. Bates No. 03537131-03537132. URL: http://www.lorillarddocs.com/

24 Cigarette Brand Switching Studies. [Undated; estimated 1984] Brown \& Williamson Tobacco Company, Inc. Access date: August 21, 2001 Bates No. 665076894-665076916. URL: http://www.bwdocs.aalatg.com/

25 National Automatic Merchandising Association. Highlights Gilbert youth research study of teen-age cigarette purchase and smoking habits. 1963. Philip Morris Companies, Inc. Access date: August 21, 2001. Bates No. 1005040468-1005040469. URL: http://www.pmdocs.com

26 Holbert N. Incidence of Smoking Cigarettes. May 18, 1973. Philip Morris Companies, Inc. Access date: August 21, 2001. Date: August 21 , 2001. Bates No. 2041761792 - 2041761796. URL

http://www.pmdocs.com

27 Geyelin M. Tobacco executive doubts product risks. Wall Street Journal 1998.

28 Johnston M., Daniel HG, Levy CJ. 8102 Young smokers - prevalence, trends, implications and related demographic trends. March 31, 1981. Philip Morris Companies, Inc. Access date: August 21, 2001. Bates No. 1000390803-1000390855. URL: http://www.pmdocs.com

29 Brown \& Williamson Tobacco Co. Young adult smoker life styles and attitudes. Brown \& Williamson Tobacco Company, Inc. 1974. Access date: August 17, 2001. Bates No. 170040977-170040986. URL: http://www.bw.aalatg.com/public.asp.
30 Marshall, I. Kool analysis of brand switching study - Wave \#18. September 10, 1975. Brown \& Williamson Tobacco Company, Inc. Access date: August 17, 2001. Bates No. 665076813 - 665076817. URL: http://www.bw.aalatg.com/public.asp.

31 Yizar R. Pontiac Kool jazz festival. August 8, 1976. Brown \& Williamson Tobacco Company, Inc. Access date: August 17, 2001. Bates No. 666011286 - 666011287 . URL: http://www.bw.aalatg.com/ public.asp.

32 Brown \& Williamson Tobacco Co. B\&W Problem Lab. G/W s; Idea April 27, 1977. Brown \& Williamson Tobacco Company, Inc. Access date: August 17, 2001. Bates No. 170040579-170040582 170041305. URL: http://www.bw.aalatg.com/public.asp.

33 Brown \& Williamson Tobacco Co. Session 3: Implications for cigarette industry. April 20, 1978. Brown \& Williamson Tobacco Company, Inc. Access date: August 17, 2001. Bates No. $667007711-667007714$. URL: http://www.bw.aalatg.com/public.asp.

34 Brown \& Williamson Tobacco Co. Cinema advertising - possibilities. 1983. Brown \& Williamson Tobacco Company, Inc. Access date: August 17, 2001. Bates No. 690132323-690132324. URL http://www.bw.aalatg.com/public.asp.

35 Medicus RP. Factors accounting for Kool volume and share decline. May 10, 1983. Brown \& Williamson Tobacco Company, Inc.. Access date: August 17, 2001. Bates No. 670579615-670579625. URL: http://www.bw.aalatg.com/public.asp

36 Brown \& Williamson Tobacco Co. Additional analyses: the national brand switching studies. January 1984. Brown \& Williamson Tobacco Company, Inc. Access date: August 17, 2001. Bates No. 670579702-670579724. URL: http://www.bw.aalatg.com/public.asp

37 Satterthwaite, FB. Faulkner, Dawkins \& Sullivan Cigarette Analysis MR7590. June 7, 1973. Lorillard Tobacco Company, Inc. Access date: August 17, 2001. Bates No. 91270029 - 91270030. URL: http://www.lorillarddocs.com.

38 Ritchie RE. Progress report - Zack Filter and Menthol. August 22, 1975 Lorillard Tobacco Company, Inc. Access date: August 17, 2001. Bates No. 91529112 - 91529114 . URL: http://www.lorillarddocs.com.

39 Marketing Corporation of America. Lorillard - New Products Work Session: LPT, LIM Next Steps. November 8, 1975. Lorillard Tobacco Company, Inc. Access date: August 17, 2001. Bates No. 03366372 03366382. URL: http://www.lorillarddocs.com.

40 Flinn JG. Number of smokers. June 10, 1977. Lorillard Tobacco Company, Inc. Access date: August 17, 2001. Bates No. 03357069 03357070. URL: http://www.lorillarddocs.com

41 Moroz LR. Re: Teenage Smoking Rates. September 2, 1983. Lorillard Tobacco Company, Inc. Access date: August 17, 2001. Bates No. 03922854. URL: http://www.lorillarddocs.com.

42 Roper B, Wilkins S. Suggestions for research to answer questions based on Philip Morris behavioral study. June 12, 1970. Philip Morris Companies, Inc. Access date: August 17, 2001. Bates No. 2026234664-2026234669. URL: http://www pmdocs com.

43 Johnston $M$. The decline in the rate of growth for Marlboro Red. May 21, 1975. Philip Morris Companies, Inc. Access date: August 17, 2001 Bates No. 1000024921-1000024927. URL: http://www.pmdocs.com.

44 Philip Morris Companies, Inc. List by Year of movies for which product was supplied in connection with Charles Pomerantz and Andrew Varela. March 1989. http://www.pmdocs.com. Philip Morris Companies, Inc. Access date: August 17, 2001. Bates No. 2025863645-2025863659

45 Teague CE. Research planning memorandum on some thoughts about new brands of cigarettes for the youth market. February 2, 1973. R J Reynolds Tobacco Company, Inc. Access date: August 17, 2001. Bates No. 502987357-502987368. URL: http://www.rirtdocs.com.

46 Colby FG. Cigarette concept to assure RIR a larger segment of the youth market. December 4, 1973. R J Reynolds Tobacco Company, Inc. Access date: August 17, 2001. Bates No. $501166152-501166153$. URL: http://www.rirtdocs.com.

47 Tredennick DW. The purpose of this memorandum is to answer the question 'What causes smokers to select their first brand of cigarettes'. July 3, 1974. R J Reynolds Tobacco Company, Inc. Access date: August 17, 2001. Bates No. 501221308-501221317. URL: http://www.rirtdocs.com.

48 Memorandum from Peggy to Betsy and David. Camel's 75th Anniversary. August 24, 1987. R J Reynolds Tobacco Company, Inc. Access date: August 17, 2001. Bates No. 507843401. URL: http://www.rirtdocs.com.

49 R J Reynolds Tobacco Co. YAS resource allocation. September 9 1988. R J Reynolds Tobacco Company, Inc. Access date: August 17, 2001. Bates No. 507181787-507181824. URL: http:// www.rjirtocs.com

50 Pittman RA. Youth market categories and target audience. January 24, 1975. Brown \&Williamson Tobacco Company. Access date: August 21 2001. Bates No. 670192436. URL: http://www.bw.aalatg.com/ public.asp.

51 Hall LW Jr. Younger adult smokers - terminology. September 11, 1980 R.J. Reynolds Tobacco Company. Access date: August 21, 2001. Bates No. 504075896. URL: http://www.rirtdocs.com.

52 Barnes M. Aging 18 year old smokers into NFO panel data. December 8, 1981. R.J. Reynolds Tobacco Company. Access date: August 21 , 2001. Bates: $503412316-503412318$. URL: http://www.rirtdocs.com.

53 Law Department. Marketing assistant training manual. May 14, 1986 R. J. Reynolds Tobacco Company. Access date: August 21, 2001 . Bates No. 521892843-521892845. URL: http://www.rirtdocs.com.

54 McMahon J. Young adult market. January 1, 1990. R. J. Reynolds Tobacco Company. Access date: August 21, 2001. Bates No. 682817261 . URL: http://www.bwdocs.aalatg.com/. 
55 McMahon J. [Letter to Sales Reps]. May 3, 1990. R. J. Reynolds Tobacco Company. Access date: August 21, 2001. Bates No. 682817262-19900503. URL: http://www.bwdocs.aalatg.com.

56 R.J. Reynolds Tobacco Co. Camel Y\&R Orientation. [Undated, estimated early 1990's]. R.J. Reynolds Tobacco Company. August 22 2001. Bates 507241613-507241679. URL: http://www.rirtdocs.com.

57 Burrows D. Younger adult smoker: strategies and opportunities. February 29, 1984. R. J. Reynolds Tobacco Company. Access date August 21, 2001. Bates No. 501928462-501929550. URL: http://www..rirtdocs.com.

58 Marlboro Brand Group. Marlboro brand review, 1992. April, 1992.1 Philip Morris. Marketing Plan (1992-1994). Philip Morris Companies, Inc. Access date: September 19, 2001. Bates No. 2501081089-2501081 104. URL: http://www.pmdocs.com

59 Philip Morris USA $1994-1998$ plan overview. Undated. Philip Morris Companies, Inc. Access date: September 19, 2001. Bates No. 2024146736-2024146768. URL: http://www.pmdocs.com.

60 US Department of Health and Human Services. Reducing tobacco use: a report of the Surgeon General. Atlanta, Georgia: US Department of Health and Human Services, Centers for Disease Control and Prevention, National Center for Chronic Disease Prevention and Health Promotion, Office on Smoking and Health, 2000.

61 Cummings KM, Sciandra E, Pechacek TF, Orlandi M, Lynn WR (for the COMMIT Research Group). Where teenagers get their cigarettes: A survey of the purchasing habits of 13 to 16 year olds in 12 U.S communities. Tobacco Control 1992;1:264-7.

62 DiFranza JF, Godshall WT. Tobacco industry efforts hindering enforcement of the ban on tobacco sales to minors: actions speak louder than words. Tobacco Control 1996;5:127-31.

63 Philip Morris Companies, Inc. Reasons for considering Camel serious competitor. 1991. Philip Morris Companies, Inc. Access date: August 22, 2001. Bates No. 2043982154-2043982 163. URL:http:// www.pmdocs.com

64 CDC. Changes in the cigarette brand preferences of adolescent smokers - United States, 1989-1993. MMWR Morb Mortal Wkly Rep 1994;43:577-81.

65 McCarthy EJ. Basic marketing: a managerial approach. Homewood, Illinois: Irwin, 1960

66 Teague CE. Proposal of a new, consumer-oriented business strategy for RJR Tobacco Company. September 19, 1969. R.J. Reynolds Tobacco Company. Access date: August 22, 2001. R.J. Bates No. 500915701 500915719. URL: http://www.rirtdocs.com.

67 Sugg W. Survey of smoking by high school and college students. December 22, 1959. R.J. Reynolds Tobacco Company. Access date: August 22, 2001. Bates No. 501113722 . http://www.rirtdocs.com.

68 Danker W. Roper Attitude Study of 19590100. May 28, 1959. Philip Morris Companies Inc. Access date: August 22, 2001. Bates No. 1001755243-1001755244. URL: http://www.pmdocs.com.

69 Sugg, W. Attached is a report of a survey of cigarette smoking as of early january, based upon returns from approximately 5,000 families and 7,500 individual smokers. March 12, 1964. R.J. Reynolds Tobacco Company. Access date: August 22, 2001. Bates No. 501795141. URL http://www rirtdocs.com

70 R.J. Reynolds Tobacco Company. Technology: Ammoniation. 1981. R.J. Reynolds Tobacco Company. Access date: August 22, 2001. Bates No. 509018864-509018865A. URL: http://www.rirtdocs.com.

71 Moore J. Correlation of $\mathrm{pH}$ with share performance. December 26 1973. R.J Reynolds Tobacco Company. Access date: August 22, 2001 Bates No. 501327013. URL: http://www.rirtdocs.com.

72 Bernasek E, Nystrom C. Ammonia. August 9, 1982. R.J. Reynolds Tobacco Company. Access date: August 22, 2001. Bates No. 504438506-504438512. URL: http://www.rirtdocs.com.

73 Marketing Innovations Inc. Project: youth cigarette - new concepts. September 1972. Access date: August 22, 2001 (Image File at B\&W cite non-functioning at time of last access - image available at http://www.tobaccodocuments.org.) Brown \& Williamson Tobacco Company. Bates No. 170042014. URL: http:// www.bwdocs.aalatg.com

74 Ritchy A. Apple wine cigarette project. December 18, 1972. R.J. Reynolds Tobacco Company. Access date August 22, 2001. Bates No. 501283430-501283431. URL: http://www.rirtdocs.com.

75 Conference report. New Products. June 5, 1974. R.J. Reynolds Tobacco Company. Access date August 22, 2001. Bates No. $521190208-521190210$. URL: http://www.rirtdocs.com.

76 Kohnhorst EE, Gorden DL. PM's global strategy: Marlboro's product technology. October 26, 1992. Brown \& Williamson Tobacco Company. Bates No. BW-SD3-0000059- BW-SD3-0000294 URL: http://www.bwdocs.aalatg.com

77 British American Tobacco Company. The current group R\&D projects 1985. British American Tobacco Company. Access date: August 22, 2001. 109870521-109870561. URL: http://

www.tobaccodocuments.org

78 R .J. Reynolds Tobacco Company. RJ Reynolds Tobacco Company domestic operating goals November 26, 1974. R.J. Reynolds Tobacco Company. Access date: August 22, 2001. Bates No. 500796928 500796934. URL: http://www.rirtdocs.com.

79 Cohen PS. New Brands and strategic research report: project XG qualitative exploratory III MDD Topline Perspective. June 14, 1982. R.J. Reynolds Tobacco Company. Access date: August 22, 2001. Bates: 502034890-502034895. URL: http://www.rirtdocs.com.

80 Browe ME, Dickerson JP. Interview With John L. Mckenzie. May 5, 1983. R.J. Reynolds Tobacco Company. Access date: August 22, 2001 Bates: 503873749-503873850. URL: http://www.rirtdocs.com.
81 Coggins C. A qualitative assessment of Camel advertising equity. 1991. R.J. Reynolds Tobacco Company. Access date: August 22, 2001. Bates No. 509045372-50904-54 16. URL: http://www.rirtdocs.com.

82 Wayne GF, Connolly GN. How cigarette design can effect youth initiation into smoking. Camel cigarettes, 1983-93. Tobacco Control 2002;11 (suppl I):i32-9.

83 Mazza M. Starch panel results: Harley Davidson LT 85's prototype (\#1386/87). January 23, 1996. Lorillard Tobacco Company, Inc. Access date August 22, 2001. Bates No. $91972002-91972005$. URL: http://www.lorillarddocs.com/.

84 Chaloupka F, Cummings KM, Morley C, et al. Tax, price and cigarette smoking: evidence from the tobacco documents and implications for tobacco company marketing strategies. Tobacco Control 2002;11/suppl l):i62-72.

85 Daniel M. Teenage Smoking and the federal excise tax on cigarettes. September 22, 1981. Philip Morris Companies, Inc. Access date: August 22, 2001. Bates No. 2022249717-2022249721. URL: http://www.pmdocs.com.

86 Johnston $M$. Teenage smoking and the federal excise tax on cigarettes. Philip Morris memorandum, September 17, 1981. Philip Morris Companies, Inc. Access date: September 28, 2001. Bates Number 1000797544. URL: http://www.pmdocs.com

87 Brubaker K. Young adult responsiveness to RJR promotions. August 24, 1979. R.J. Reynolds Tobacco Company. Access date: August 22, 2001 Bates: 500686342-500686350. URL: http://www.rirtdocs.com.

88 Shapiro E. New price move By Philip Morris intensifies war. Wall Street Journal, July 21, 1993: B1, B8.

89 Sumner W, Dillman G. A fist full of coupons: cigarette continuity programmes. Tobacco Control 1994;4:245-52

90 Richard JW, DiFranza JR, Fletcher C, et al. RJ Reynolds' Camel cash: another way to reach kids. Tobacco Control 1995:4:258-60.

91 Zollo P. Wise up to teens: insights into marketing and advertising to teenagers. Ithaca, New York: New Strategist Publications, Inc, 1995.

92 Martin CA. Younger adult smoker perception of Camel. October 18, 1984. R.J. Reynolds Tobacco Company. Access date: August 22, 2001 Bates No. 503561565-503561570. URL: http://www.rirtdocs.com.

93 Memorandum from R.T. Caufield to D.N. Iauco. Camel new advertising campaign development. March 12, 1986. . R. J. Reynolds Tobacco Company. Access date: September 19, 2001. Bates: 503969238-503969242. URL: http://www.rirtdocs.com.

94 Katz SK, Lavack AM. Tobacco-related bar promotions: insights from tobacco industry documents. Tobacco Control 2002;11/suppl I):i92-101

95 Tucker RC. Marlboro resort program. February 13, 1976. Philip Morris Companies, Inc. Access date: August 22, 2001. Bates No. 2045015714-2045015717. URL: http://www.pmdocs.com.

96 Stirlan RL. Marlboro spring program. January 10, 1975. Philip Morris Companies, Inc. Access date: August 22, 2001. Bates No. 2045015823-2045015828. URL: http://www.pmdocs.com

97 Robinson WA. Marlboro youth resort program. June 1977. Philip Morris Companies, Inc., Access date: August 22, 2001. Bates No. 2045015656-2045015659. URL: http://www.pmdocs.com

98 Philip Morris Companies, Inc. Marlboro. March 29, 1979. Philip Morris Companies, Inc. Access date: August 22, 2001. Bates: 2043828174 - 2043828176. URL: http://www.pmdocs.com.

99 Philip Morris Companies, Inc. 840000 Marlboro spring resort field marketing opportunities. 1984. Philip Morris Companies, Inc. Access date: August 22, 2001. Bates No. 2044390059-2044390073. URL: http://www.pmdocs.com.

100 Philip Morris Cos., Inc. Marlboro adventure team flex fund promotions for retail masters full participants who accept the MAT promotion. November 23, 1992. Philip Morris Cos., Inc. Access date: August 22, 2001. Bates No. 2042538958-2002538968. URL: http:// www.pmdocs.com.

101 Philip Morris Companies, Inc. Marlboro adventure team image study. July 1993, Philip Morris Companies, Inc. Access date: August 22, 2001 Bates No. 2042581409-2042581521. URL: http://www.pmdocs.com.

102 Coach T, Schuyler B, Schuyler M. Adventure team Marlboro. March 5, 1993. Philip Morris Companies, Inc. Access date: August 22, 2001 Bates No. 2044934347- 2044934348. URL: http://www.pmdocs.com.

103 Ricci E, MCA-Graham Advertising. Lorillard Newport Lights box basis for interest. January 5, 1979. Lorillard Tobacco Company, Inc. Access date: August 22, 2001. Bates No. 85087247-850872454. URL: http://www.lorillarddocs.com/.

104 Action Marketing Ltd. Kool jazz festival and Kool country shindig fina recommendations November 10,1978. Brown and Williamson Tobacco Corporation. Bates: 666022850-666022898. URL: http:// www.tobaccodocuments.org.

105 Harlle GC, William Esty Company. R.J. Reynolds Tobacco Company Winston box marketing plan. November 1973. R.J. Reynolds Tobacco Company. Access date: August 22, 2001. Bates No. 500724265-500724313. URL: http://www.rirtdocs.com

106 Warlick RG. Young adult market SIS Account Grouping. April 5, 1990. R.J. Reynolds Tobacco Company. Access date: August 22, 2001. Bates No. 508082544. URL: http://www.rirtdocs.com.

107 Cowan W. Rogers and Cowan Inc. [Re: Recap RJR Yearly Activities of RJR.] May 5, 1981 . R.J. Reynolds Tobacco Company. Access date: August 22, 2001. Bates No. 503579240-503579244. URL: http://www.rirtdocs.com.

108 Philip Morris Companies, Inc. Marlboro. Philip Morris Companies, Inc 1987. Access date: August 22, 2001. Bates No. 2044732959. 2044732963. URL: http://www.pmdocs.com. 
109 Mekemson C, Glantz SA. How the tobacco industry built its relationship with Hollywood. Tobacco Control 2002;11 (suppl I):i89-91.

110 Walker B, Universal Pictures. [Re: American Graffiti Motion Picture.] October 25, 1972. R.J. Reynolds Tobacco Company. Access date: August 22, 2001. Bates No. 500201433. URL: http:// www.rirtdocs.com.

111 Spengler P, Dovemead Limited. Superman II - The Movie. October 18, 1979. Philip Morris Companies, Inc. Access date: August 22, 2001 Bates No. 2046788819-204678821. URL: http://www.pmdocs.com.

112 Hendricks JL. KOOL record continuity. September 7, 1983. Brown and Williamson Tobacco Corporation. Access date: August 22, 2001. Bates No. 676026171-676026172. URL: http://www.bwdocs.aalatg.com/ public.asp

113 Ripslinger JF. Associated Film Promotions. [Re: Stallone Tobacco Use Agreement.] June 14, 1983. Brown and Williamson Tobacco Corporation. Access date: August 22, 2001. Bates No. 685083120. URL: http://www.bwdocs.aalatg.com/public.asp.

114 Brown \& Williamson Tobacco Company. B\&W Product Placement in Movies. [Undated, estimated mid-1980's]. Brown \& Williamson Tobacco Company. Bates: 685086492-685086501. URL: http:// www.tobaccodocuments.org.

115 Philip Morris USA. Marketing Plan (1992-1996). Undated. Philip Morris Companies, Inc. Access date: September 19, 2001. Bates No. 2021508238-2021508242. URL: http://www.pmdocs.com.

116 Morrissey M. Young and Rubicam. As per our discussion, the following items in-house or in storage will be destroyed. October 31, 1991. R. J. Reynolds Tobacco Company. Access date: August 22, 2001. Bates: 507647971 - 507647975. URL: http://www.rirtdocs.com.

117 Pollay RW. Promises, promises: self-regulation of US cigarette broadcast advertising in the 1960s. Tobacco Control 1994:3:134-44.

118 King C III, Siegel M. The Master Settlement Agreement with the tobacco industry and cigarette advertising in magazines. N Engl J Med 2001;345:504-11.

119 Centers for Disease Control and Prevention. Changes in the cigarette brand preferences of adolescent smokers - United States, 1989-1993. MMWR Morb Mortal Wkly Rep 1994;43:577-81

120 Hwang S. Philip Morris tests new menthol type of Marlboro brand. Wall Street Journal, July 26, 1999, p B5; Philip Morris to begin testing new menthol version of Marlboro, Bloomberg News, July 26, 1999. (Post
Date: 07/26/99) from Shttp://www.kickbutt.org/news/scarchives/ 9907-july/990726.html>|

121 Roswell Park Cancer Institute. Survey of alcohol, tobacco and drug use among ninth grade students, 2000-01: Erie County. Buffalo, New York: Roswell Park Cancer Institute, Department of Cancer Prevention, Epidemiology and Biostatistics, August 2001.

122 Centers for Disease Control and Prevention. Tobacco use and usual source of cigarettes among high school students - United States, 1995. MMWR Morb Mortal Wkly Rep 1996;45:413-18.

123 Investor Responsibility Research Center. Tobacco Information Service, 1999 Company Report. Philip Morris Companies, Inc., April 7 1999.; also see: Harper CM. Letter to stockholders of the RJR Nabisco Holding Corportion, March 20, 1995; and: Seward J, R.J. Reynolds holders ax proposal on ads, youth smoking, Dow Jones New Service, April 19, 2000

124 Mahood G. Warnings that tell the truth: breaking new ground in Canada. Tobacco Control 1999;8:356-61

125 Sherman SJ, Cialdini RB, Schwartzman DF, et al. Imagining can heighten or lower the perceived likelihood of contracting a disease: the mediating effect of ease of imagery. Personality and Social Psychology Bulletin 1985;11:118-27.

126 Health Canada. When packages can't speak: possible impacts of plain and generic packaging of tobacco products. Expert Panel Report. March 1985.

127 Slovic P. Smoking: risk, perception \& policy. Thousand Oaks, California: Sage Publications, Inc, 2001

128 Slovic $\mathbf{P}$. What does it mean to know a cumulative risk? Adolescents perceptions of short-term and long-term consequences of smoking. Journal of Behavioral Decision Making 2000;13:259-66.

129 Cummings KM. Do smokers' really understand the risks of smoking Presentation made to the Office on Smoking and Health at the Center For Disease Control and Prevention, May 25, 2001

130 Kwechansky Marketing Research, Inc. Report for: Imperial Tobacco Limited - Subject: Project Plus/Minus. May 7, 1982. Brown \& Williamson Tobacco Company Inc. Access date: August 22, 2001. Bates No. 566627751-566627824. URL: http://www.bw.aalatg.com/public.asp

131 Pollay RW, Dewhirst T. The dark side of marketing seemingly "Light" cigarettes: successful images and failed fact. Tobacco Control 2002;11 (suppl I):i18-31.
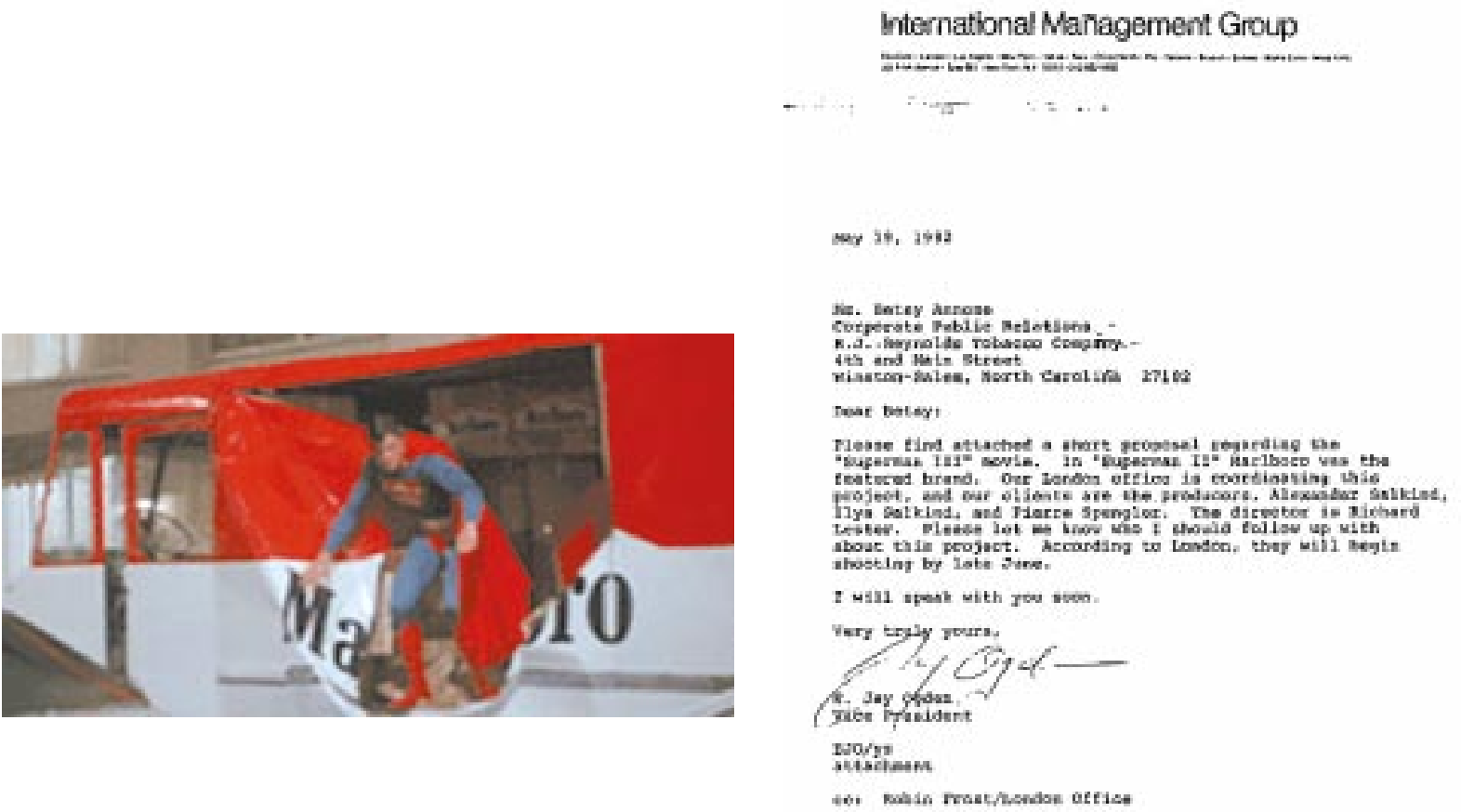